\title{
Effect of salt concentrations on in vitro rumen fermentation of cellulose, starch, and protein
}

\author{
E.C.B. Costa ${ }^{1}$, G.G.L. Araújo ${ }^{2}$, J.S. Oliveira ${ }^{1}$, E.M. Santos ${ }^{1}$, L.T. Henriques ${ }^{1}$, A.F. Perazzo ${ }^{3}$, \\ A.M. Zanine ${ }^{4 \#}$, G.A. Pereira ${ }^{1}$ \& R.M.A. Pinho ${ }^{4}$ \\ ${ }^{1}$ Department of Animal Science, Federal University of Paraíba, PB, 58397-000, Areia, Brazil \\ ${ }^{2}$ Brazilian Enterprise for Agricultural Research, Pernambuco, PE, 56302-970, Petrolina, Brazil \\ ${ }^{3}$ Department of Animal Science, State University of Bahia, Salvador, BA, 40210-730, Brazil \\ ${ }^{4}$ Department of Animal Science, Federal University of Maranhão, MA, 65500-000, Maranhão, Brazil
}

(Received 9 January 2019; Accepted 18 October 2019; First published online 31 January 2020)

\begin{tabular}{|} 
Copyright resides with the authors in terms of the Creative Commons Attribution 4.0 South African Licence. \\
See: http://creativecommons. org/licenses/by/4.0/za \\
Condition of use: The user may copy, distribute, transmit and adapt the work, but must recognise the authors and the South African \\
Journal of Animal Science.
\end{tabular}

\begin{abstract}
The aim of this study was to evaluate the effects of various concentrations of three salts (sodium chloride $(\mathrm{NaCl})$, magnesium chloride $\left(\mathrm{MgCl}_{2}\right)$, and calcium chloride $\left(\mathrm{CaCl}_{2}\right)$ ) on the in vitro rumen fermentation of cellulose, starch, and protein substrates. Six salt concentrations were tested, separately, namely $0,100,200,400,800$, and $1600 \mathrm{mg} / \mathrm{dL}$. The experiment was conducted using the completely randomized design in a $6 \times 3 \times 3$ factorial arrangement with main effects of salt concentration and salt type (six levels of three salts $\left(\mathrm{NaCl}, \mathrm{MgCl}_{2}\right.$, or $\left.\mathrm{CaCl}_{2}\right)(0,100,200,400,800$, and $1600 \mathrm{mg} / \mathrm{dL}$ ) into three substrates [starch, cellulose, and glucose]) with three replicates. Cellulose- and glucose-fermenting bacteria were sensitive to $\mathrm{NaCl}$ concentrations greater than $400 \mathrm{mg} / \mathrm{dL}(17.48$ decisiemens per metre $(\mathrm{dS} / \mathrm{m}))$ and $800 \mathrm{mg} / \mathrm{dL}(20.55 \mathrm{dS} / \mathrm{m})$ in the media, respectively. In contrast, starch-fermenting bacteria continued to grow in $\mathrm{NaCl}$ concentrations up to $1600 \mathrm{mg} / \mathrm{dL}(29.09 \mathrm{dS} / \mathrm{m})$. Thus, it was concluded that starch-fermenting microorganisms tolerated higher concentrations of $\mathrm{NaCl}$ compared with the other microbial groups. Cellulose-fermenting microorganisms are less tolerant to $\mathrm{MgCl}_{2}$ in relation to the other microbial groups. Starch, cellulose-, and glucose-fermenting bacteria from cattle tolerate $\mathrm{CaCl}_{2}$ concentrations of up to 1600 $\mathrm{mg} / \mathrm{dL}(12.26 \mathrm{dS} / \mathrm{m})$. These results suggest that brackish water may be used for ruminants. However, it is important perform an analysis of that water and then to adjust diets to minimize the effects of types of salt and concentrations of salt on rumen microorganisms.
\end{abstract}

Keywords: brackish water, dissolved salts, rumen microbes, water quality

\#Corresponding author: anderson.zanine@ibest.com.br

\section{Introduction}

Water is becoming increasingly scarce in the world as a result of the population growth and of its improper management and use (El-Keblawy \& Al-Shamsi, 2008). It is estimated that less than half of the world population has access to adequate drinking water. Water is a necessary nutritional component in all stages of animal production. Minimizing its importance, in addition to generating health problems, compromises animal production (Araujo et al., 2010).

The supply of brackish water to ruminants can pose health risks, depending on the concentration and composition of the dissolved salts. Animals can tolerate different salinity contents according to their species, age, water intake level, and physiological conditions (NRC, 2007; Alves et al., 2017). Additionally, the semiarid regions of the planet commonly present a large seasonal variation in rainfall distribution over the year, culminating in irregular availability and quality of water for animal consumption (Descheemaeker et al., 2010). Besides, many coastal regions have a high content of salt (mainly $\mathrm{NaCl}$ ) in their water resulting from the mixture of fresh and sea water, which also makes it more difficult to feed all animals in this region with plentiful quality water (Visscher et al., 2013).

Limited information is available in the literature regarding the tolerance of rumen microorganisms to different levels of minerals in the water (El Shaer, 2010). This knowledge is of paramount importance for 
semi-arid and coastal regions, given the varied population of ruminants in these areas and the competition among these animals for the scarce drinking water that is already used by the human population. A large portion of brackish waters have a high concentrations of Chlorine (Cl), Magnesium (Mg), Calcium (Ca), and Sodium ( $\mathrm{Na}$ ) ions, mainly in the form of $\mathrm{NaCl}, \mathrm{MgCl}_{2}$, and $\mathrm{CaCl}_{2}$ salts (Manera et al., 2016), and constitute important sources to these animals. Thus, the aim of the present study was to evaluate the effect of different concentrations of $\mathrm{NaCl}, \mathrm{MgCl}_{2}$, and $\mathrm{CaCl}_{2}$ on the in vitro rumen fermentation of cellulose, starch, and protein.

\section{Materials and Methods}

This study was undertaken in accordance with the technical norms of biosafety and ethics, on approval by the Ethics Committee in the Use of Animals of the Centre for Biotechnology (CBiotec) of the Federal University of Paraíba (UFPB) (document no. 022/2012). In vitro trials were carried out at the Laboratory of Forage Crops at the Department of Animal Science of UFPB, Areia - PB, Brazil, from October 2013 to August 2014. The experiment involved a 3-year-old rumen-cannulated bullock that was housed at the Unit for Research with Large Ruminants at the Department of Animal Science of UFPB. It was fed with a mixed ration composed of $80 \%$ fresh grass and $20 \%$ concentrate (ground corn and soybean meal).

Rumen fluid was collected manually two hours before feeding to obtain inoculant containing active microbial population, which was transported to the laboratory. At the laboratory, the fluid was saturated with carbon dioxide, and left to rest at $39^{\circ} \mathrm{C}$, After the formation of liquid interfaces, the intermediate fluid was collected and centrifuged at $500 \times g$ for $10 \mathrm{~min}$, while the supernatant was discarded to obtain an inoculant that contained active microbial populations (Oliveira et al., 2012). The residue from centrifugation (pellet), which contained predominant bacteria in the rumen fluid, was re-suspended in McDougall's buffer (9.80 g $\mathrm{NaHCO}_{3} ; 4.65 \mathrm{~g} \mathrm{Na}_{2} \mathrm{HPO}_{4}{ }_{2} \mathrm{H}_{2} \mathrm{O} ; 0.57 \mathrm{~g} \mathrm{KCl} 0.12 \mathrm{~g} \mathrm{MgSO}_{4}{ }^{\star} 7 \mathrm{H}_{2} \mathrm{O}$; and $0.04 \mathrm{~g} \mathrm{CaCl}_{2}$, diluted in distilled water up to the volume of $1000 \mathrm{~mL}$ ).

The effects of $\mathrm{NaCl}, \mathrm{MgCl}_{2}$, and $\mathrm{CaCl}_{2}$ in various concentrations in the culture media were evaluated in isolation. Six concentrations of the three salts were tested, namely $0,100,200,400,800$, and $1600 \mathrm{mg} / \mathrm{dL}$. Each treatment was replicated three times. This experiment was conducted as a completely randomized design in a $6 \times 3 \times 3$ factorial arrangement consisting of six concentrations of $\mathrm{NaCl}, \mathrm{MgCl}_{2}$, and $\mathrm{CaCl}_{2}(0$, $100,200,400,800$, and $1600 \mathrm{mg} / \mathrm{dL}$ ) in three substrates (starch, cellulose, and glucose), with three replicates.

Each incubation bottle was filled with $20 \mathrm{~mL}$ of growth medium $(16 \mathrm{~mL}$ McDougall's buffer and $4 \mathrm{~mL}$ inoculant), $150 \mathrm{mg}$ substrate, and the concentrations of the salt. Starch, cellulose, and glucose were used as substrates for the rumen microorganisms. Treatments were composed as shown in Table 1.

Table 1 Distribution of treatments according to substrate, salt type and the salt concentration

\begin{tabular}{|c|c|c|c|c|c|c|}
\hline \multirow{3}{*}{$\begin{array}{l}\text { Substrate } \\
\text { Starch }\end{array}$} & \multicolumn{6}{|c|}{ Salt concentration } \\
\hline & \multicolumn{6}{|c|}{$\mathrm{NaCl}$} \\
\hline & 0 & 100 & 200 & 400 & 800 & 1600 \\
\hline Cellulose & 0 & 100 & 200 & 400 & 800 & 1600 \\
\hline \multirow[t]{2}{*}{ Glucose } & 0 & 100 & 200 & 400 & 800 & 1600 \\
\hline & \multicolumn{6}{|c|}{$\mathrm{MgCl}_{2}$} \\
\hline Starch & 0 & 100 & 200 & 400 & 800 & 1600 \\
\hline Cellulose & 0 & 100 & 200 & 400 & 800 & 1600 \\
\hline \multirow[t]{2}{*}{ Glucose } & 0 & 100 & 200 & 400 & 800 & 1600 \\
\hline & \multicolumn{6}{|c|}{$\mathrm{CaCl}_{2}$} \\
\hline Starch & 0 & 100 & 200 & 400 & 800 & 1600 \\
\hline Cellulose & 0 & 100 & 200 & 400 & 800 & 1600 \\
\hline Glucose & 0 & 100 & 200 & 400 & 800 & 1600 \\
\hline
\end{tabular}

$\mathrm{NaCl}$ : sodium chloride, $\mathrm{MgCl}_{2}$ : Magnesium chloride, $\mathrm{CACl}_{2}$ : Calcium chloride

All bottles were saturated with carbon dioxide, closed with special lids, and sealed with adhesive tape to prevent contact with the external medium. Next, they were incubated at $39{ }^{\circ} \mathrm{C}$ in a water bath under 
agitation (35 rpm) for 48 hours. During this period, the incubation times of $0,6,12,24$, and 48 hours were evaluated by collecting the fluid with syringes to prevent the entry of oxygen. All gas produced was removed with a needle, which remained for 10 seconds at each of the incubation times. The $\mathrm{pH}$ was measured with a digital potentiometer at incubation times of 0 and 48 hours. At zero time, the medium was saturated with carbon dioxide to maintain the $\mathrm{pH}$ between 6.00 and 7.00 , in all treatments. Each time a $2.0 \mathrm{~mL}$ sample was collected from the culture medium of each experimental unit and placed in Eppendorf ${ }^{\circledR}$ tubes, which were then centrifuged in a microcentrifuge at $1200 \times g$ for $10 \mathrm{~min}$. The supernatant was frozen for analyses of ammonia nitrogen $\left(\mathrm{NH}_{3}-\mathrm{N}\right)$ and volatile fatty acids (VFA). The pellet that was formed, which contained the predominating microorganisms in the rumen fluid, was re-suspended in $0.9 \%$ saline solution, homogenized, and re-centrifuged at $1200 \times g$ for $10 \mathrm{~min}$. The supernatant was discarded. The pellet that was formed during the last centrifugation was re-suspended in $0.9 \%$ saline solution and frozen at $-10^{\circ} \mathrm{C}$ for later analysis of microbial protein, which was performed according to the methodology proposed by Makkar et al. (1982).

For the analysis of VFA, $500 \mu \mathrm{L}$ of supernatant was collected, to which $500 \mu \mathrm{L} 25 \%$ metaphosphoric acid was added and placed in Eppendorf ${ }^{\circledR}$ tubes. The material was analysed in a high-performance liquid chromatograph (HPLC) coupled to an ultraviolet (UV) detector, at a wavelength of $210 \mathrm{~nm}$. Ammonia nitrogen analyses were performed by the colorimetric method, while protein was quantified by the method of Bradford (1976). Electric conductivity (dS/m) was measured at zero time and at 48 hours of incubation, using a conductivity meter.

The experimental design was completely randomized, with six concentrations of salt, three types of salt and three substrates, according to the statistical model below:

$$
Y_{i j k l}=\mu+\alpha_{i}+\beta_{j}+\delta_{k}\left(\alpha \beta_{i j}\right)+\left(\alpha \delta_{i k}\right)+\left(\beta \delta_{j k}\right)+\left(\alpha \beta \delta_{i j k}\right)+B_{z}\left(\beta_{j}\right)+\varepsilon_{i j k l},
$$

Where: $Y_{\mathrm{ijkl}}=$ the $\mathrm{I}^{\text {th }}$ observation of a dependent variable;

$\mu=$ overall mean;

$\alpha_{i}=$ fixed effect of $i^{\text {th }}$ concentrations of salt;

$\beta_{j}=$ fixed effect of ${ }^{\text {th }}$ substrate;

$\delta_{k}$ fixed effect of $k^{\text {th }}$ salt type;

$\alpha \beta_{i j}=$ interaction between levels of salt and substrate;

$\alpha \delta_{i k j}=$ interaction between levels of salt and salt type;

$\alpha \beta \delta_{i j k}=$ interaction between levels of salt, substrate and salt type;

$B_{z}\left(\beta_{j}\right)=$ effect of $z^{\text {th }}$ blocks within the substrate; and

$\varepsilon_{\mathrm{ijkl}}=$ error associated with observation $\mathrm{Y}_{\mathrm{ijk} \mathrm{l}}$.

All statistical analyses were performed in SAS ${ }^{\circledR}$ System for Windows ${ }^{\text {TM }} 9.4$ (SAS Institute Inc., Cary, NC, USA, 2015). Null hypotheses were rejected at the significance level 0.05. Data were subjected to univariate analysis of variance via the GLM (general linear models) procedure and to regression analysis.

\section{Results}

Sodium chloride, $\mathrm{MgCl}_{2}$ and $\mathrm{CaCl}_{2}$ levels had an increasing linear effect $(P<0.05)$ on the conductivity of the medium (Table 2). The substrates had no differences in conductivity when compared with the same $\mathrm{NaCl}$ concentrations. However, when compared within the same $\mathrm{MgCl}_{2}$ and $\mathrm{CaCl}_{2}$ concentrations, cellulose was the substrate with the highest conductivity values.

There was a quadratic $(P<0.05)$ effect of $\mathrm{NaCl}$ content on microbial protein concentration after 48 hours of incubation in the medium that contained glucose (Table 3). According to the regression equation, maximum microbial growth was estimated at $\mathrm{NaCl}$ concentration of $880 \mathrm{mg} / \mathrm{dL}$ when the substrate was glucose, with microbial protein production of $1899.04 \mathrm{mg} / \mathrm{dL}$.

The media that contained cellulose did not differ $(P<0.05)$ from that containing starch up to $\mathrm{NaCl}$ concentrations of $400 \mathrm{mg} / \mathrm{dL}$ in terms of microbial protein concentration (Table 3). Cellulolytic microorganisms were sensitive to $\mathrm{NaCl}$, reducing their microbial production linearly $(P<0.05)$ as the concentration of this salt in the media was elevated.

The medium that contained starch had the highest $(P<0.05)$ concentration of microbial protein when compared with cellulose and glucose in the presence of $\mathrm{MgCl}_{2}$ (Table 3). Magnesium chloride had a quadratic effect $(P<0.05)$ on the growth of cellulolytic bacteria. The regression equation indicated greatest microbial growth at $\mathrm{MgCl}_{2}$ concentration of $751 \mathrm{mg} / \mathrm{dL}$ (Table 2).

Media that contained starch and glucose did not differ $(P<0.05)$ in microbial protein values at the $\mathrm{CaCl}_{2}$ levels (Table 3). However, lower concentrations of microbial protein were produced when the media included the substrate cellulose, indicating that the microorganisms that use it as a source of energy are sensitive to high levels of calcium chloride (Table 3). There was a quadratic effect on the concentration of 
microbial protein in the medium that contained cellulose, with the lowest growth of these microorganisms estimated at the $\mathrm{CaCl}_{2}$ concentration of $1.175 \mathrm{mg} / \mathrm{dL}$ (Table 3). Calcium chloride salt concentrations caused a decreasing linear effect on microbial protein production in glucose and starch substrates, so it was inferred that increased $\mathrm{CaCl}_{2}$ salt concentrations possibly affected microbial activity (Table 3).

Table 2 Mean values of conductivity $(\mathrm{dS} / \mathrm{m})$ of growth medium in vitro at different concentrations of sodium chloride magnesium chloride and calcium chloride

\begin{tabular}{|c|c|c|c|c|c|c|c|c|c|}
\hline \multirow{2}{*}{ Substrate } & \multicolumn{6}{|c|}{ Concentrations of salt $(\mathrm{mg} / \mathrm{dL})$} & \multicolumn{3}{|c|}{$P$-value } \\
\hline & 0 & 100 & 200 & 400 & 800 & 1600 & SE & $\mathrm{L}$ & $\mathrm{Q}$ \\
\hline \multicolumn{10}{|c|}{$\mathrm{NaCl}$} \\
\hline Starch & $10.23^{\mathrm{a}}$ & $11.31^{\mathrm{a}}$ & $12.38^{a}$ & $14.57^{\mathrm{a}}$ & $21.03^{\mathrm{a}}$ & $33.84^{a}$ & & $<0.0001$ & 0.1621 \\
\hline Cellulose & $9.89^{\mathrm{a}}$ & $10.62^{\mathrm{a}}$ & $11.45^{\mathrm{a}}$ & $13.98^{\mathrm{a}}$ & $20.24^{\mathrm{a}}$ & $33.20^{\mathrm{a}}$ & 1.45 & $<0.0001$ & 0.1003 \\
\hline Glucose & $10.39^{a}$ & $11.38^{\mathrm{a}}$ & $11.94^{\mathrm{a}}$ & $14.10^{a}$ & $16.71^{b}$ & $32.59^{a}$ & & $<0.0001$ & $<0.0001$ \\
\hline \multicolumn{10}{|c|}{$\mathrm{MgCl}_{2}$} \\
\hline Starch & $11.70^{b}$ & $12.04^{b}$ & $12.51^{b}$ & $13.25^{b}$ & $15.26^{b}$ & $18.49^{b}$ & & $<0.0001$ & 0.4061 \\
\hline Cellulose & $13.51^{\mathrm{a}}$ & $13.88^{\mathrm{a}}$ & $14.11^{\mathrm{a}}$ & $14.92^{a}$ & $16.46^{\mathrm{a}}$ & $22.61^{a}$ & 0.14 & $<0.0001$ & $<0.0001$ \\
\hline Glucose & $11.44^{\mathrm{b}}$ & $11.85^{\mathrm{b}}$ & $12.24^{\mathrm{b}}$ & $13.05^{b}$ & $14.61^{\mathrm{c}}$ & $18.33^{b}$ & & $<0.0001$ & 0.0102 \\
\hline \multicolumn{10}{|c|}{$\mathrm{CaCl}_{2}$} \\
\hline Starch & $10.86^{\mathrm{C}}$ & $11.43^{\mathrm{b}}$ & $11.70^{\mathrm{b}}$ & $12.50^{\mathrm{b}}$ & $15.54^{b}$ & $28.49^{b}$ & & $<0.0001$ & $<0.0001$ \\
\hline Cellulose & $13.69^{\mathrm{a}}$ & $14.12^{\mathrm{a}}$ & $14.43^{\mathrm{a}}$ & $14.98^{a}$ & $17,55^{\mathrm{a}}$ & $31.01^{a}$ & 0.34 & $<0.0001$ & $<0.0001$ \\
\hline Glucose & $11.62^{b}$ & $12.01^{b}$ & $11.97^{\mathrm{b}}$ & $12.53^{b}$ & $16.03^{b}$ & $28.29^{b}$ & & $<0.0001$ & $<0.0001$ \\
\hline
\end{tabular}

Within salt, column means with different superscripts differ significantly at $P<0.05$

$\mathrm{NaCl}$ : sodium chloride, $\mathrm{MgCl}_{2}$ : Magnesium chloride, $\mathrm{CACl}_{2}$ : Calcium chloride

Table 3 Mean values of microbial protein $(\mathrm{mg} / \mathrm{dl})$, after 48 hours of in vitro incubation at different concentrations of sodium chloride, magnesium chloride and calcium chloride

\begin{tabular}{|c|c|c|c|c|c|c|c|c|c|}
\hline \multirow{2}{*}{ Substrate } & \multicolumn{6}{|c|}{ Concentrations of salt (mg/dL) } & \multirow[t]{2}{*}{ SE } & \multicolumn{2}{|c|}{$P$-value } \\
\hline & 0 & 100 & 200 & 400 & 800 & 1600 & & L & Q \\
\hline \multicolumn{10}{|c|}{$\mathrm{NaCl}$} \\
\hline Starch & $792.1^{b}$ & $872.4^{\mathrm{b}}$ & $831.3^{\mathrm{b}}$ & $765.8^{b}$ & $876.6^{b}$ & $675.8^{b}$ & & 0.1930 & 0.3330 \\
\hline Cellulose & $635.8^{\mathrm{b}}$ & $781.3^{\mathrm{b}}$ & $826.6^{\mathrm{b}}$ & $848.8^{\mathrm{b}}$ & $572.9^{c}$ & $526.0^{b}$ & 140.7 & 0.0139 & 0.4530 \\
\hline Glucose & $1536.1^{\mathrm{a}}$ & $1876.1^{\mathrm{a}}$ & $1848.7^{\mathrm{a}}$ & $1683.5^{\mathrm{a}}$ & $1899.0^{\mathrm{a}}$ & $1257.6^{\mathrm{a}}$ & & 0.0002 & $<0.0001$ \\
\hline \multicolumn{10}{|c|}{$\mathrm{MgCl}_{2}$} \\
\hline Starch & $3612.5^{\mathrm{a}}$ & $3407.5^{\mathrm{a}}$ & $3665.8^{\mathrm{a}}$ & $3459.2^{\mathrm{a}}$ & $4635.8^{\mathrm{a}}$ & $2005.8^{c}$ & & 0.1113 & 0.4298 \\
\hline Cellulose & $2279.1^{c}$ & $2580.8^{b}$ & $2764.1^{b}$ & $2844.2^{b}$ & $3150.8^{b}$ & $2702.5^{\mathrm{b}}$ & 184.7 & 0.6445 & $<0.0001$ \\
\hline Glucose & $3130.8^{b}$ & $3640.8^{a}$ & $4077.5^{\mathrm{a}}$ & $2829.2^{b}$ & $2777.5^{\mathrm{b}}$ & $3237.5^{\mathrm{a}}$ & & $<0.0001$ & $<0.0001$ \\
\hline \multicolumn{10}{|c|}{$\mathrm{CaCl}_{2}$} \\
\hline Starch & $888.9^{a}$ & $871.1^{a}$ & $740.0^{\mathrm{ab}}$ & $757.8^{\mathrm{a}}$ & $798.9^{a}$ & $894.4^{a}$ & & 0.0081 & 0.0004 \\
\hline Cellulose & $317.8^{b}$ & $502.2^{\mathrm{a}}$ & $425.6^{\mathrm{b}}$ & $534.4^{\mathrm{a}}$ & $281.11^{\mathrm{b}}$ & $421.1^{b}$ & 237.7 & 0.1746 & 0.0039 \\
\hline Glucose & $911.1^{a}$ & $841.1^{a}$ & $903.3^{a}$ & $883.3^{a}$ & $674.44^{a}$ & $555.6^{\mathrm{ab}}$ & & 0.0005 & 0.0009 \\
\hline
\end{tabular}

Different superscript letters within the column differ significantly at $P<0.05$

$\mathrm{NaCl}$ : sodium chloride, $\mathrm{MgCl}_{2}$ : Magnesium chloride, $\mathrm{CACl}_{2}$ : Calcium chloride 
There was an increasing linear effect $(P<0.05)$ of the $\mathrm{NaCl}$ and $\mathrm{CaCl}_{2}$ concentrations in the medium that contained cellulose for $\mathrm{NH}_{3}-\mathrm{N}$ production (Table 4). No effect of $\mathrm{NaCl}$ salt concentrations was detected $(P<0.05)$ on $\mathrm{NH}_{3}-\mathrm{N}$ production in the medium that contained glucose (Table 4). Sodium chloride salt levels promoted a quadratic negative effect on $\mathrm{NH}_{3}-\mathrm{N}$ production in medium that contained starch (Table 4).

Magnesium chloride levels in the medium that contained cellulose promoted a quadratic negative effect on $\mathrm{NH}_{3}-\mathrm{N}$ production (Table 4). No effect of $\mathrm{MgCl}_{2}$ was observed $(P<0.05)$ on ammonia nitrogen production in the medium with starch and glucose (Table 4). In the medium that contained starch, a lower $\mathrm{NH}_{3}-\mathrm{N}$ content was detected in relation to cellulose and glucose at the $\mathrm{CaCl}_{2}$ levels of 800 and $1600 \mathrm{mg} / \mathrm{dL}$ (Table 4).

Table 4 Mean values of ammonia nitrogen content after 48 hours of in vitro incubation at different concentrations of sodium chloride, magnesium chloride and calcium chloride

\begin{tabular}{|c|c|c|c|c|c|c|c|c|c|}
\hline \multirow{2}{*}{ Substrate } & \multicolumn{7}{|c|}{ Concentrations of salt (mg/dL) } & \multicolumn{2}{|c|}{$P$-value } \\
\hline & 0 & 100 & 200 & 400 & 800 & 1600 & SE & L & Q \\
\hline \multicolumn{10}{|c|}{$\mathrm{NaCl}$} \\
\hline Starch & $9.11^{a}$ & $5.25^{a}$ & $7.86^{\mathrm{ab}}$ & $5.06^{\mathrm{a}}$ & $5.61^{b}$ & $10.88^{\mathrm{b}}$ & \multirow{3}{*}{3.13} & 0.1710 & 0.0402 \\
\hline Cellulose & $3.93^{\mathrm{a}}$ & $6.23^{\mathrm{a}}$ & $6.29^{b}$ & $10.60^{\mathrm{a}}$ & $22.46^{\mathrm{a}}$ & $26.91^{\mathrm{a}}$ & & $<.0001$ & 0.0116 \\
\hline \multirow[t]{2}{*}{ Glucose } & $7.58^{\mathrm{a}}$ & $5.95^{a}$ & $12.83^{\mathrm{a}}$ & $8.58^{\mathrm{a}}$ & $6.26^{b}$ & $8.26^{\mathrm{b}}$ & & 0.7648 & 0.8670 \\
\hline & \multicolumn{7}{|c|}{$\mathrm{MgCl}_{2}$} & & \\
\hline Starch & $4.61^{b}$ & $4.94^{\mathrm{b}}$ & $5.46^{b}$ & $2.31^{b}$ & $4.18^{b}$ & $5.25^{b}$ & \multirow{3}{*}{1.67} & 0.7430 & 0.1387 \\
\hline Cellulose & $13.87^{\mathrm{a}}$ & $14.71^{a}$ & $9.47^{\mathrm{a}}$ & $7.49^{\mathrm{a}}$ & $10.51^{\mathrm{a}}$ & $16.35^{\mathrm{a}}$ & & 0.0101 & $<.0001$ \\
\hline \multirow[t]{2}{*}{ Glucose } & $6.14^{\mathrm{b}}$ & $4.75^{b}$ & $4.51^{\mathrm{b}}$ & $6.19^{\mathrm{a}}$ & $4.71^{\mathrm{b}}$ & $4.50^{\mathrm{b}}$ & & 0.4041 & 0.9867 \\
\hline & \multicolumn{7}{|c|}{$\mathrm{CaCl}_{2}$} & & \\
\hline Starch & $1.93^{\mathrm{a}}$ & $2.15^{\mathrm{a}}$ & $1.84^{\mathrm{b}}$ & $5.23^{\mathrm{a}}$ & $1.29^{\mathrm{C}}$ & $0.37^{\mathrm{c}}$ & \multirow{3}{*}{1.49} & 0.0527 & 0.1075 \\
\hline Cellulose & $3.60^{\mathrm{a}}$ & $4.03^{\mathrm{a}}$ & $5.22^{\mathrm{a}}$ & $4.29^{\mathrm{a}}$ & $10.72^{\mathrm{a}}$ & $17.70^{\mathrm{a}}$ & & $<.0001$ & 0.2842 \\
\hline Glucose & $2.88^{\mathrm{a}}$ & $4.46^{\mathrm{a}}$ & $2.84^{\mathrm{ab}}$ & $4.52^{\mathrm{a}}$ & $4.30^{b}$ & $4.25^{\mathrm{b}}$ & & 0.3725 & 0.4336 \\
\hline
\end{tabular}

Different superscript letters within the column differ significantly at $P<0.05$

$\mathrm{NaCl}$ : sodium chloride, $\mathrm{MgCl}_{2}$ : Magnesium chloride, $\mathrm{CACl}_{2}$ : Calcium chloride

There was a decreasing linear effect $(P<0.05)$ of the $\mathrm{NaCl}$ concentration in the media that contained starch, cellulose, and glucose after 48 hours of incubation on the concentration of acetate (Table 5). There was no difference $(P<0.05)$ between the substrates in the $\mathrm{NaCl}$ salt concentration from 200 to $1600 \mathrm{mg} / \mathrm{dL}$.

The $\mathrm{NaCl}$ concentrations had a quadratic effect $(P<0.05)$ on propionate concentration when the substrates starch and cellulose were used (Table 5). The propionate content varied $(P<0.05)$ in the medium that contained starch, with lowest concentrations estimated at $660 \mathrm{mg} / \mathrm{dL} \mathrm{NaCl}$. In the medium that contained cellulose, the propionate concentration decreased linearly $(P<0.05)$ with $\mathrm{NaCl}$ concentration. However, at the $\mathrm{NaCl}$ concentration of $1600 \mathrm{mg} / \mathrm{dL}$, the medium that contained starch had higher propionate contents than the media that included cellulose and glucose (Table 5).

There was a quadratic effect $(P<0.05)$ of $\mathrm{NaCl}$ concentrations in the medium with starch and a decreasing linear effect in the media that contained either cellulose or glucose on butyrate concentrations after 48 hours of incubation (Table 5). In the medium that contained starch, the highest butyrate concentration was estimated at the $\mathrm{NaCl}$ concentration of $120 \mathrm{mg} / \mathrm{dL}$, with production of approximately 13.74 $\mathrm{mM}$ (Table 5).

No effect of substrate was detected $(P<0.05)$ on the concentration of acetate in the media that contain either $\mathrm{MgCl}_{2}$ or $\mathrm{CaCl}_{2}$ after 48 hours of incubation (Table 6). By contrast, there was a negative quadratic effect $(P<0.05)$ of $\mathrm{MgCl}_{2}$ levels after 48 hours of incubation, with the lowest acetate concentration being found at $130 \mathrm{mg} / \mathrm{dL}$. Thus, no effect of the substrates was observed $(P<0.05)$ in the media with $\mathrm{MgCl}_{2}$ and $\mathrm{CaCl}_{2}$ on acetate propionate and butyrate contents. There was a negative quadratic effect $(P<0.05)$ for $\mathrm{MgCL}_{2}$, with lowest propionate concentration $(16.76 \mathrm{mM}$ ) estimated at $200 \mathrm{mg} \mathrm{MgCl} / \mathrm{dL}$. There was no effect $(P<0.05)$ of $\mathrm{CaCl}_{2}$ on propionate and butyrate production which averaged 16.23 and $8.73 \mathrm{mM}$, respectively (Table 6). 
Table 5 Mean values of acetate, propionate and butyrate content (mM) after 48 hours of in vitro incubation at different concentrations of sodium chloride

\begin{tabular}{|c|c|c|c|c|c|c|c|c|c|}
\hline \multirow{2}{*}{ Substrate } & \multicolumn{7}{|c|}{$\mathrm{NaCl}$ Concentrations (mg/dL) } & \multicolumn{2}{|c|}{$P$-value } \\
\hline & 0 & 100 & 200 & 400 & 800 & 1600 & SE & $\mathrm{L}$ & Q \\
\hline \multicolumn{10}{|c|}{ Acetate $(\mathrm{mM})$} \\
\hline Starch & $34.00^{\mathrm{ab}}$ & $41.24^{a}$ & $37.83^{a}$ & $31.49^{\mathrm{a}}$ & $28.59^{a}$ & $32.23^{\mathrm{a}}$ & & 0.0200 & 0.0300 \\
\hline Cellulose & $38.99^{\mathrm{a}}$ & $35.35^{\mathrm{ab}}$ & $37.74^{\mathrm{a}}$ & $25.96^{\mathrm{a}}$ & $22.31^{\mathrm{a}}$ & $25.21^{\mathrm{a}}$ & 3.90 & $<0.0001$ & 0.0002 \\
\hline Glucose & $26.77^{\mathrm{b}}$ & $31.71^{b}$ & $30.91^{\mathrm{a}}$ & $26.52^{\mathrm{a}}$ & $25.66^{\mathrm{a}}$ & $24.43^{\mathrm{a}}$ & & 0.0488 & 0.7552 \\
\hline \multicolumn{10}{|c|}{ Propionate (mM) } \\
\hline Starch & $22.78^{\mathrm{ab}}$ & $25.98^{a}$ & $26.70^{a}$ & $21.67^{\mathrm{a}}$ & $18.13^{\mathrm{a}}$ & $25.29^{a}$ & & 0.6689 & 0.0079 \\
\hline Cellulose & $25.67^{\mathrm{a}}$ & $22.43^{\mathrm{a}}$ & $26.02^{\mathrm{ab}}$ & $16.58^{\mathrm{a}}$ & $12.30^{\mathrm{a}}$ & $15.04^{b}$ & 3.10 & $<0.0001$ & 0.0003 \\
\hline Glucose & $18.31^{b}$ & $20.68^{a}$ & $20.25^{\mathrm{b}}$ & $16.83^{\mathrm{a}}$ & $16.64^{\mathrm{a}}$ & $14.91^{b}$ & & 0.0265 & 0.7176 \\
\hline \multicolumn{10}{|c|}{ Butyrate (mM) } \\
\hline Starch & $11.60^{\mathrm{ab}}$ & $13.74^{\mathrm{a}}$ & $13.53^{\mathrm{a}}$ & $11.22^{\mathrm{a}}$ & $9.55^{a}$ & $13.41^{\mathrm{a}}$ & & 0.9536 & 0.0090 \\
\hline Cellulose & $13.57^{\mathrm{a}}$ & $10.89^{\mathrm{a}}$ & $13.83^{\mathrm{a}}$ & $8.83^{\mathrm{a}}$ & $6.38^{\mathrm{a}}$ & $7.95^{\mathrm{b}}$ & 1.64 & $<0.0001$ & 0.0004 \\
\hline Glucose & $9.41^{b}$ & $11.31^{\mathrm{a}}$ & $11.00^{\mathrm{a}}$ & $8.84^{a}$ & $8.72^{\mathrm{a}}$ & $8.00^{b}$ & & 0.0263 & 0.6687 \\
\hline
\end{tabular}

Different superscript letters within the column differ significantly at $P<0.05$

$\mathrm{NaCl}$ : sodium chloride

Table 6 Mean values of acetate, propionate, and butyrate content $(\mathrm{mM})$, after 48 hours of in vitro incubation at different concentrations of salt

\begin{tabular}{|c|c|c|c|c|c|c|c|c|c|}
\hline \multirow{2}{*}{ Salt } & \multicolumn{7}{|c|}{ Concentrations of salt (mg/dl) } & \multicolumn{2}{|c|}{$P$-value } \\
\hline & 0 & 100 & 200 & 400 & 800 & 1600 & SE & L & Q \\
\hline \multicolumn{10}{|c|}{ Acetate $(\mathrm{mM})$} \\
\hline $\mathrm{MgCl}_{2}$ & 26.06 & 23.65 & 25.34 & 22.98 & 22.42 & 24.63 & 2.24 & 0.3344 & 0.0018 \\
\hline $\mathrm{CaCl}_{2}$ & 24.56 & 24.22 & 24.07 & 24.35 & 25.37 & 19.81 & 5.10 & 0.0521 & 0.1527 \\
\hline \multicolumn{10}{|c|}{ Propionate (mM) } \\
\hline $\mathrm{MgCl}_{2}$ & 17.71 & 15.64 & 16.76 & 14.86 & 14.75 & 16.65 & 2.04 & 0.5953 & 0.0025 \\
\hline $\mathrm{CaCl}_{2}$ & 17.26 & 15.84 & 15.47 & 17.29 & 16.72 & 14.98 & 3.32 & 0.3326 & 0.4579 \\
\hline \multicolumn{10}{|c|}{ Butyrate (mM) } \\
\hline $\mathrm{CaCl}_{2}$ & 8.82 & 8.21 & 9.01 & 9.21 & 9.05 & 8.12 & 1.70 & 0.4780 & 0.2187 \\
\hline
\end{tabular}

$\mathrm{MgCl}_{2}$ : Magnesium chloride, $\mathrm{CACl}_{2}$ : Calcium chloride

The $\mathrm{MgCl}_{2}$ concentrations in the medium that contained cellulose had no effects $(P<0.05)$ after 48 hours of incubation on the butyrate concentration (Table 7). However, $\mathrm{MgCl}_{2}$ in the media that contained either starch or glucose had a quadratic effect $(P<0.05)$ on butyrate production, with the lowest values estimated at 240 and $180 \mathrm{mg} / \mathrm{dL}$, respectively. This quadratic effect may be associated with the change in microbial population at $\mathrm{MgCl}_{2}$ concentrations higher than 240 and $180 \mathrm{mg} / \mathrm{dL}$ in the media with starch and glucose, respectively. 
Table 7 Mean values of butyrate content $(\mathrm{mM})$, after 48 hours of in vitro incubation at different concentrations of magnesium chloride

\begin{tabular}{lrllllllll}
\hline \multirow{2}{*}{ Substrate } & \multicolumn{1}{c}{$\mathrm{MgCl}_{2}$ Concentrations $(\mathrm{mg} / \mathrm{dL})$} & \multicolumn{3}{c}{$P$-value } \\
\cline { 2 - 10 } & 0 & 100 & 200 & 400 & 800 & 1600 & $\mathrm{SE}$ & $\mathrm{L}$ & $\mathrm{Q}$ \\
\hline Starch & 9.37 & 8.07 & 7.62 & 6.86 & 8.01 & 8.78 & & 0.6955 & 0.0470 \\
Cellulose & 8.24 & 8.50 & 9.15 & 9.55 & 7.85 & 8.46 & 1.17 & 0.6475 & 0.8541 \\
Glucose & 10.43 & 7.92 & 8.95 & 7.51 & 7.67 & 8.94 & & 0.5563 & 0.0093 \\
& & & & & & & & & \\
\hline
\end{tabular}

$\mathrm{MgCl}_{2}$ : Magnesium chloride

\section{Discussion}

For animals, as excess total dissolved solids in water (TDS) are increased, the water quality declines, leading to decreased intake and poor performance (Umar et al., 2014). According to these authors, water with salinity levels that are greater than $700 \mathrm{mg} / \mathrm{dL}$ poses a great risk to young, pregnant, and lactating animals. Saline water can thus negatively affect rumen microbial growth. The presence of foreign solutes reduces the ability of the water to dissolve additional solutes, which may influence the osmolarity of the cell plasma. Solutes exert an inadequate attraction on the water through the membranes, making the water movement an inhibitor of microbial activity (Al-Khalasi et al., 2010). However, various strains of ruminal microorganisms can tolerate amounts greater than $700 \mathrm{mg} / \mathrm{dL}$ of $\mathrm{NaCl}$ or $\mathrm{MgCl}_{2}$, or $\mathrm{CaCl}_{2}$ (Table 3). The presence of $\mathrm{NaCl}$ in the media up to $880 \mathrm{mg} / \mathrm{dL}$ and $\mathrm{CaCl}_{2}$ up to $1175 \mathrm{mg} / \mathrm{dL}$ did not interfere with the growth of cellulolytic microorganisms. The microorganisms grown on media that contained starch did not have their growth affected by salt concentrations up to $1600 \mathrm{mg} / \mathrm{dL}$, demonstrating that amylolytic microorganisms are more tolerant of high salinity levels.

The substrate that provided the greatest microbial growth at all concentrations of $\mathrm{NaCl}, \mathrm{MgCl}_{2}$, and $\mathrm{CaCl}_{2}$ was glucose (Table 3). Glucose is the monosaccharide that composes fibrous (cellulose and hemicellulose) and non-fibrous (starch, amylopectin, and others) carbohydrates. Glucose is freed from plant polymers (fibrous carbohydrates) and starch through enzymatic systems associated with membranes from bacteria that hydrolyse $\beta$ bonds (endocellulase and exocellulases) and $\alpha$ bonds (amylases and endoglycosidases), releasing glucose in the media (Oliveira et al., 2008). It can then be used as an energy source by fibrous and non-fibrous carbohydrate-fermenting microorganisms, possibly stimulating growth in the culture media of both fermenter groups. Thus, in the media that contained glucose, the presence of salts that inhibited only one group of microorganisms favoured the growth of another group that was not sensitive (Tables 3 and 4). Only when the salt inhibited the growth of the two groups (amylolytic or cellulolytic) or drastically inhibited a group was a reduction observed in the concentration of microbial protein in the media. This could be observed when there were high $\mathrm{NaCl}$ concentrations in the media (Table 3).

Valtorta et al. (2008) did not find any effect of water salinity on the rumen parameters (microorganism count, $\mathrm{pH}$, and VFA) of dairy cows. However, the microbial growth of cellulolytic bacteria declined as the presence of TDS was increased from 100 to $1000 \mathrm{mg} / \mathrm{dL}$. Thomas et al. (2007) also observed a decrease in bacteria when the rumen $\mathrm{NaCl}$ concentration was increased, demonstrating compromised rumen function. Alves et al. (2017) observed a reduction of neutral detergent fibre digestibility when cattle consumed saline water with a high $\mathrm{NaCl}$ content, which the current results corroborate, with a linear decreasing effect for the acetate contents as there were increases in the concentration of $\mathrm{NaCl}$ (Table 5).

According to Oliveira et al. (2008), structural carbohydrate-fermenting bacteria that degrade cellulose and hemicellulose from the plant cell wall have a relatively slower growth rate and depend on ammonia and branched-chain fatty acids (isovalerate, isobutyrate, and 2-methylbutyrate) for protein synthesis. The growth of amylolytic bacteria is faster when compared with that of cellulolytic bacteria, which provide a higher concentration of microorganisms and consequently greater microbial protein production in the media that contained starch and glucose. This low growth speed of cellulolytic microorganisms is described in Table 2, which shows that the microorganisms had a higher microbial protein concentration with the substrates of glucose $\left(1899.04 \mathrm{mg} / \mathrm{dL}\right.$ with $\mathrm{NaCl}$ and $903.3 \mathrm{mg} / \mathrm{dL}$ with $\mathrm{CaCl}_{2}$ ) and starch $\left(4635.8 \mathrm{mg} / \mathrm{dL}\right.$ with $\mathrm{MgCl}_{2}$ and $894.4 \mathrm{mg} / \mathrm{dL}$ with $\mathrm{CaCl}_{2}$ ) than with cellulose $\left(572.9 \mathrm{mg} / \mathrm{dL}\right.$ with $\mathrm{NaCl}, 3150.8 \mathrm{mg} / \mathrm{dL}$ with $\mathrm{MgCl}_{2}$, and 421.19 $\mathrm{mg} / \mathrm{dL}$ with $\mathrm{CaCl}_{2}$ ).

Valtorta et al. (2008) also observed a gradual increase in ammonia concentration in the rumen environment as they elevated the water salinity level to 100,500 , and $1000 \mathrm{mg} / \mathrm{dL}$ TDS, in dairy cows. When the $\mathrm{NaCl}$ levels were increased, there was a linear decrease in microbial protein content and an increase in 
the concentration of ammonia in the medium that contained cellulose (Tables 3 and 4). Magnesium chloride and $\mathrm{CaCl}_{2}$ did not interfere with the cellulose digestion. Ammonia is essential for the growth of structural carbohydrate-degrading bacteria (Figueiras et al., 2010). Therefore, ammonia accumulation in the media may be a consequence of inhibition of cellulolytic microorganisms in the media by $\mathrm{NaCl}$.

Microorganisms that ferment cellulose have the acetate pathway as the main NADH re-oxidation route (Oliveira et al. 2008). In this way, the lower concentration of this VFA in the media may be associated with lower microbial growth and increasing concentration of $\mathrm{NaCl}$. In this study, when the $\mathrm{CaCl}_{2}$ levels in the media were increased, acetate production decreased. The microorganisms that use the acetate pathway for re-oxidation of $\mathrm{NADH}_{2}$ are probably sensitive to the $\mathrm{CaCl}_{2}$ levels in the media or change their $\mathrm{NADH}_{2}$ reoxidation route.

When the media is not conducive to the re-oxidation of NADH via the acetate pathway, some bacterial species use the propionate pathway for this purpose, because the metabolism of microorganisms can be changed without modifying their species (Nussio et al., 2011). The lack of effect of $\mathrm{CaCl}_{2}$ on propionate production demonstrates that microorganisms that used the acetate pathway did not change the NADH reoxidation route to propionate, indicating that the inhibition of acetate production was linked to a reduction of bacterial species that use the acetate pathway for the re-oxidation of $\mathrm{NAD}^{+}$(Table 7). This can be verified by the reduced concentration of microbial protein in the media with cellulose (Table 3).

Acetyl CoA is a precursor of both acetate and butyrate (Valadares \& Pina, 2011). Many bacteria utilize the butyrate pathway for the re-oxidation of NADH. However, some bacterial species present this route only for this purpose, irrespective of the hydrogen pressure in the media (Oliveira et al. 2008). In this way, the butyrate-producing bacteria are sensitive to the $\mathrm{NaCl}$ in the media. Potassium is the main intracellular cation; sodium is the main extracellular cation; and chloride is the main extracellular anion. The relative concentrations of these three elements create an electrochemical gradient through the cell membranes that is essential for nutrient transport and generation of energy, and they contribute indirectly to the maintenance of $\mathrm{pH}$ balance. Imbalances among these elements result in a number of disorders that may culminate in death of microbial cells (Umar et al., 2014).

In the media that contain starch as substrate, a lower effect of $\mathrm{NaCl}$ salt was observed on microorganisms, even when there were elevated concentrations of this salt in the media, demonstrating that amylolytic microorganisms are less sensitive to $\mathrm{NaCl}$. On the other hand, in the medium that contained cellulose, there was a decreasing linear effect of this salt in the media, likely due to the inhibition of cellulolytic microorganisms. This response is observed by the lower concentrations of microbial protein, acetate and propionate in the media and higher ammonia production when $\mathrm{NaCl}$ was increased. Cellulolytic microorganisms are likely sensitive to $\mathrm{NaCl}$ in the medium.

In the medium that contained glucose, there was a decline in microbial growth and VFA production at the $\mathrm{NaCl}$ concentration of $1600 \mathrm{mg} / \mathrm{dL}$ and an increase in the levels of ammonia in the medium. Rumen microorganisms seem to be sensitive to $\mathrm{NaCl}$ concentrations greater than $1600 \mathrm{mg} / \mathrm{dL}$ or $29.09 \mathrm{dS} / \mathrm{m}$ in the medium. Therefore, when cattle consume water with high levels of $\mathrm{NaCl}$, microbial fermentation in the rumen may be affected, especially when the diet has larger proportions of fibrous carbohydrates.

In the medium that had starch as substrate, a lower effect of $\mathrm{CaCl}_{2}$ was observed on microorganisms, even when high concentrations of this salt were present, suggesting that amylolytic microorganisms are less sensitive to $\mathrm{CaCl}_{2}$. By contrast, in the medium with cellulose and glucose, salt levels greater than 1600 $\mathrm{mg} / \mathrm{dL}$ inhibited microorganism growth. This response is verified by the lower concentrations of microbial protein and volatile fatty acids and greater ammonia concentration when $1600 \mathrm{mg} \mathrm{CaCl} / \mathrm{dL}_{2}$ were present in the medium. Cellulolytic and glycolytic microorganisms seem to be sensitive to $\mathrm{CaCl}_{2}$ concentrations greater than $1600 \mathrm{mg} / \mathrm{dL}$ or $12.26 \mathrm{dS} / \mathrm{m}$ in the medium.

In the media where starch and glucose were used as substrate, a lower effect of the $\mathrm{MgCl}_{2}$ salt was observed on the present microorganisms, even when there were elevated concentrations of this salt in the medium, indicating that amylolytic microorganisms are less sensitive to $\mathrm{MgCl}_{2}$. In the medium that contained cellulose, however, beyond the salt level of $400 \mathrm{mg} / \mathrm{dL}$, microorganism growth was inhibited. This response is verified by the lower concentrations of microbial protein and volatile fatty acids and larger ammonia production when the medium contained $400 \mathrm{mg} \mathrm{MgCl} / \mathrm{dL}$.

\section{Conclusions}

Starch-fermenting microorganisms tolerate higher concentrations of $\mathrm{NaCl}$ when compared with the other microbial groups. However, cellulose-fermenting microorganisms are less tolerant to $\mathrm{MgCl}_{2}$. In the present work, starch-, cellulose-, and glucose-fermenting bacteria that originated from cattle tolerated $\mathrm{CaCl}_{2}$ concentrations of up to $1600 \mathrm{mg} / \mathrm{dL}(12.26 \mathrm{dS} / \mathrm{m})$. The results obtained in this study indicate that brackish water may be used to ruminants. However, it is important to perform an analysis of that water and, then, according to this analysis, to adjust diets to minimize the effects of these salts on rumen microorganisms. 


\section{Acknowledgements}

The authors wish to thank FAPEMA (Maranhão State Research Foundation) for its financial support.

\section{Authors' Contributions}

The idea for the study was conceived by EMS, who secured the funding and supervised GGLA, JSO, EMS and AMZ. ECBC was recruited as the student to work on the project and received her MSc cum laude. ECBC, LTH and GAP performed the experiment. AFP and RMAP were responsible for statistical analysis and structuring the manuscript formatting. EMS was the supervisor at the university and gave guidance on the study. All co-authors participated in management and discussion of the results, statistical analysis and writing, and corrected the manuscript. All authors read and approved the final manuscript.

\section{Conflict of Interest Declaration}

The authors declare there are no conflicts of interest.

\section{References}

Al-Khalasi, S.S., Mahgoub, O, Kadim, I.T., Al-Marzooqi, W. \& Al-Rawahi, S.A., 2010. Salt tolerant fodder for Omani sheep (effects of salt-tolerant sorghum on performance, carcass, meat quality and health of Omani sheep). In: A. Mushtaque, S.A. Al-Rawahi \& N. Hussain, (eds). Monograph on management of salt-affected soils and water for sustainable agriculture. Sultan Qaboos University, Oman. pp. 67-81.

Alves, J.N., Araújo, G.G.L., Neto, S.G., Voltolini, T.V., Santos, D.R., Rosa, P.R., Guan, L., McAllister, T. \& Neves, A.L.A., 2017. Effect of increasing concentrations of total dissolved salts in drinking water on digestion, performance and water balance in heifers. J Agri. Sci. 38, 1309-1316.

Araújo, G.G.L.D., Voltolini, T.V., Chizzotti, M.L., Turco, S.H.N. \& Carvalho, F.F.R.D., 2010. Water and small ruminant production. Braz. J. Anim. Sci. 39, 326-336.

Bradford, M.M., 1976. Rapid and sensitive method for quantitation of microgram quantities of protein utilising principle of protein dye binding. Analyt. Biochem. 72, 248-254.

Descheemaeker, K., Amede, T. \& Haileslassie, A., 2010. Improving water productivity in mixed crop-livestock farming systems of sub-Saharan Africa. Agric. Water Man. 97, 579-586.

El-Keblawy, A. \& Al-Shamsi, N., 2008. Effects of salinity, temperature and light on seed germination of Haloxylon salicornicum, a common perennial shrub of the Arabian deserts. Seed Sci. Technol. 36, 679-688.

El Shaer, H.M., 2010. Halophytes and salt-tolerant plants as potential forage for ruminants in the Near East region. Small Rum. Res. 91, 3-12.

Figueiras, J.F., Detmann, E., Paulino, M.F., Valente, T.N.P., Valadares Filho, S.D.C. \& Lazzarini, I., 2010. Intake and digestibility in cattle under grazing supplemented with nitrogenous compounds during dry season. Braz. J. Anim. Sci. 39, 1303-1312.

Makkar, H.P.S., Sharma, O.P., Dawra, R.K. \& Negi, S.S., 1982. Simple determination of microbial protein in rumen liquor. J. Dairy Sci. 65, 2170-2173.

Manera, D.B., Voltolini, T.V., Menezes, D.R. \& Araújo, G.L., 2016. Chemical composition of drilled wells water for ruminants. J. Agri. Sci. 8, 127-138.

National Research Council (NRC), 2007. Nutrient requirements of small ruminants. Natl. Acad. Press, Washington, DC.

Nussio, L.G., Campos., F.P. \& Lima, M.L., 2011. Metabolismo de carboidratos estruturais. In: T.T. Berchielli, A.V. Pirez \& S.G. Oliveira (eds). Nutrição de ruminantes. FUNEP, Jaboticabal, 182-228. (Portuguese)

Oliveira, J.S., Queiroz, A.C.D., Mantovani, H.C., Bayão, G.F.V., Detmann, E., Santos, E.M. \& Silva, T.C.D., 2012. Evaluation of whey fermented by Enterococcus faecium in consortium with Veilonella parvula in ruminant feeding. Braz. J. Anim. Sci. 41, 172-180.

Oliveira, J.S., Zanine, A.M. \& Santos, E.M., 2008. Microbial diversity in the ruminal ecosystem. J. Vet. 8, 1-12.

Thomas, D.T., Rintoul, A.J. \& Masters, D.G., 2007. Sheep select combinations of high and low sodium chloride, energy and crude protein feed that improve their diet. Appl. Anim. Behav. Sci. 105, 140-153.

Umar, S., Munir, M.T., Azeem, T., Ali, S., Umar, W., Rehman, A. \& Shah, M.A., 2014. Effects of water quality on productivity and performance of livestock: A mini review. Vet. 2, 11-15.

Valadares Filho, S.C. \& Pina, D.S., 2011. Ruminal Fermentation. In: T.T. Berchielli, A.V. Pirez \& S.G. Oliveira (eds). Nutrição de Ruminantes. FUNEP, Jaboticabal, 182-228.

Valtorta, E.S., Gallardo, M.R., Sbodio, O.A., Revelli, G.R., Arakaki, C., Leva, E.P. \& Gaggiotti, M., 2008. Water salinity effects on performance and rumen parameters of lactating grazing Holstein cows. Int. J. Biometeorol. 52, 239247.

Visscher, C.F., Witzmann, S., Beyerbach, M. \& Kamphues, J., 2013. Watering cattle (young bulls) with brackish water A hazard due to its salt content? Tierärztl. Prax. 41, 363-370. 